DIKDAS MATAPPA: Jurnal Ilmu Pendidikan Dasar

Vol, 2. No, 2. September 2019 p-ISSN: 2620-5246 dan e-ISSN: 2620-6307

Link: http://journal.stkip-andi-matappa.ac.id/index.php/dikdas

(c) (1) This work is licensed under a Creative Commons Attribution

4.0 International License

\title{
PENGARUH LINGKUNGAN SEKOLAH DAN KEFEKTIFAN BELAJAR TERHADAP PRESTASI BELAJAR IPS DI SD KIP MACCINI
}

\author{
Wahyullah Alannasir ${ }^{1^{*}}$, Nurhayati Selvi ${ }^{2}$ \\ ${ }^{1}$ Dosen PGSD Universitas Islam Makassar \\ Email: wahyullah69@gmail.com \\ ${ }^{2}$ Dosen PGSD Universitas Islam Makassar \\ Email: nurhayatiselvi778@gmail.com
}

\begin{abstract}
This study aims to determine (i) the influence of the school environment on social studies learning outcomes; (ii) the effect of learning effectiveness on social studies learning outcomes; and (iii) the joint effect of the school environment and the effectiveness of learning on social studies learning outcomes at Maccini KIP Elementary School. Ex post facto research method. Questionnaire data collection techniques. The population is all students of Maccini KIP elementary school consisting of 12 classes. The sampling technique used was multistage random sampling to obtain 113 students. Data analysis techniques are descriptive and inferential. The results showed that the school environment of the school did not have a significant influence on students' social studies learning outcomes at SD KIP Maccini. The effectiveness of learning has a significant effect on students' social studies learning outcomes at Maccini KIP Elementary School. This shows that if the effectiveness of learning is high then student learning outcomes are also high. The school environment and the effectiveness of joint learning have a significant effect on students' social studies learning outcomes at SD KIP Maccini. This shows that the interaction between the school environment and the effectiveness of learning will show high student learning outcomes.
\end{abstract}

Keywords: school environment; learning effectiveness; learning outcomes.

\begin{abstract}
Abstrak: Penelitian ini bertujuan mengetahui (i) pengaruh lingkungan sekolah terhadap prestasi belajar IPS; (ii) pengaruh keefektifan belajar terhadap prestasi belajar IPS; dan (iii) pengaruh secara bersama-sama lingkungan sekolah dan keefektifan belajar terhadap prestasi belajar IPS di SD KIP Maccini. Metode Penelitian ex post facto. Teknik pengumpulan data kuesioner. Populasinya seluruh siswa SD KIP Maccini yang terdiri dari 12 rombel. Teknik penyampelan yang digunakan multistage random sampling sehingga diperoleh 113 siswa. Teknik analisis data yaitu deskriptif dan inferensial. Prestasi penelitian menunjukkan bahwa lingkungan sekolah sekolah tidak memberikan pengaruh yang berarti terhadap prestasi belajar IPS siswa di SD KIP Maccini. Keefektifan belajar berpengaruh signifikan terhadap prestasi belajar IPS siswa di SD KIP Maccini. Hal ini menunjukkan bahwa jika keefektifan pembelajaran tinggi maka prestasi belajar siswa juga tinggi. Lingkungan sekolah dan keefektifan pembelajaran bersama-sama berpengaruh signifikan terhadap prestasi belajar IPS siswa di SD KIP Maccini. Hal ini menunjukkan bahwa interaksi antara lingkungan sekolah dan keefektifan pembelajaran akan menunjukkan prestasi belajar siswa yang tinggi.
\end{abstract}

Kata Kunci: lingkungan sekolah; keefektifan pembelajaran; prestasi belajar. 


\section{PENDAHULUAN}

Sistem pendidikan di Indonesia baik melalui pendidikan formal maupun nonformal telah berkembang pesat. Hal ini sebagai realisasi dari program pembangunan pendidikan yang terus digalakkan oleh pemerintah sejak pembangunan zaman kemerdekaan sampai masa reformasi sekarang ini. Jadi, sistem pendidikan nasional tetap menjadi tumpuan harapan masyarakat dan pemerintah dalam meningkatkan kualitas hidup rakyat Indonesia.

Usaha untuk meningkatkan kualitas pendidikan, pemerintah terus melakukan pembenahan. Hal itu sebagai upaya pencapaian fungsi dan tujuan pendidikan nasional, sebagaimana ditegaskan dalam UndangUndang Nomor 20 tahun 2003 tentang Sistem Pendidikan Nasional Pasal 3 (2003:7) yaitu mengembangkan kemampuan dan membentuk watak serta peradaban bangsa yang bermartabat dalam rangka mencerdaskan kehidupan bangsa, bertujuan untuk berkembangnya potensi peserta didik agar menjadi manusia yang beriman dan bertaqwa kepada Tuhan Yang Maha Esa, berakhlak mulia, sehat, berilmu, cakap, kreatif, mandiri, dan menjadi warga negara yang demokratis serta bertanggungjawab.

Usaha-usaha yang dilakukan untuk menanamkan nilai-nilai dan norma-norma tersebut serta mewariskannya kepada generasi berikutnya untuk dikembangkan dalam hidup dan kehidupan yang terjadi dalam suatu proses pendidikan. Karenanya bagaimanapun peradaban suatu masyarakat, di dalamnya berlangsung dan terjadi suatu proses pendidikan sebagai usaha manusia untuk melestarikan hidupnya, atau dengan kata lain bahwa pendidikan dapat diartikan sebagai suatu prestasi peradaban bangsa yang dikembangkan atas dasar pandangan hidup bangsa itu sendiri (nilai dan norma masyarakat yang berfungsi sebagai filsafat) pendidikannya atau sebagai cita-cita dan pernyataan tujuan pendidikannya.

Pendidikan bagi kehidupan umat manusia merupakan kebutuhan mutlak yang harus dipenuhi sepanjang hayat. Tanpa pendidikan sama sekali mustahil suatu kelompok manusia dapat hidup berkembang sejalan dengan aspirasi (cita-cita) untuk maju, sejahtera dan bahagia menurut konsep pandangan hidup mereka.

Lingkungan belajar merupakan bagian dari proses belajar yang menciptakan tujuan belajar. Lingkungan belajar tidaklah lepas dari keberadaan siswa dalam belajar. Kebiasaan belajar siswa dipengaruhi oleh kebiasaan siswa dalam belajar di sekolah, di rumah, maupun di masyarakat.kebiassaan yang efektif berdampak pada lingkungan belajarnya. Lingkungan belajar yang baik harus diikuti dengan penguatan yang diberikan oleh guru dengan maksimal pula. Keberadaan guru sebagai motivator menjadi penting ketika memacu proses belajar peserta didik.

Lingkungan sekolah sangat berperan penting dalam proses belajar siswa. Sarana dan prasarana yang terdapat di sekolah sangat diperlukan dalam proses pembelajaran. Sarana dan prasarana yang tidak lengkap akan membuat proses pembelajaran terhambat. Begitu juga dengan peran guru dalam proses pembelajaran yang digunakan oleh guru dalam menyampaikan materi kepada siswa.Sedangkan lingkungan pendidikan adalah berbagai faktor yang berpengaruh terhadap pendidikan atau berbagai lingkungan tempat berlangsungnya proses pendidikan. Jadi, lingkungan sekolah adalah kesatuan ruang dalam lembaga pendidikan formal yang memberikan pengaruh pembentukan sikap dan pengembangan potensi siswa.

Untuk mencapai prestasi belajar yang tinggi diperlukan adanya pelakasanaan belajar yang efektif. Belajar dengan menggunakan cara yang efektif serta memperhatikan waktu dalam belajar maka akan diperoleh prestasi belajar yang optimal. Setiap siswa akan bias belajar dengan efektif asalkan mau melatih menggunakan waktu seefisien mungkin.

Berdasarkan Prestasi Observasi dan wawancara yang diadakan di SD Kip Maccini bahwa lingkungan sekolah sudah tergolong cukup baik dimana sarana dan prasarana sudah memadai dalam hal berkecukupan. Namun, Prestasi belajar siswa tergolong masih rendah yang dimana dipengaruhi oleh keefektifan dalam proses pembelajaran.Maka dari itu, berdasarkan masalah yang terjadi di atas penulis tertarik untuk meneliti tentang pengaruh lingkungan sekolah dan keefektifan 
belajar terhadap prestasi belajar IPS Di SD Kip Maccini”.

Berdasarkan latar belakang diatas maka yang menjadi rumusan masalah dalam penelitian ini adalah: (1) Adakah pengaruh lingkungan sekolah terhadap prestasi belajar IPS siswa kelas IV SD Kip Maccini ? (2) Adakah pengaruh keefektifan belajar terhadap prestasi belajar IPS siswa kelas IV SD Kip Maccini ? (3) Seberapa besar pengaruh antara lingkungan sekolah dan keefektifan belajar terhadap prestasi belajar IPS siswa kelas IV SD Kip Maccini ?

Pada prinsipnya tujuan yang ingin dicapai di dalam penelitian ini adalah untuk mengetahui: (1) Pengaruh lingkungan sekolah terhadap prestasi belajar IPS siswa kelas IV SD Kip Maccini; (2) Pengaruh keefektifan belajar terhadap prestasi belajar IPS siswa kelas IV SD Kip Maccini; (3) Seberapa besar pengaruh lingkungan sekolah dan keefektifan belajar terhadap prestasi belajar IPS siswa kelas IV SD Kip Maccini.

Lingkungan sekolah merupakan lingkungan pendidikan utama yang kedua. Siswa-siswa, guru, administrator, konselor hidup bersama dan melaksanakan pendidikan secara teratur dan terencana dengan baik (Hasbullah 2013). Menurut (Dalyono 2015), lingkungan sekolah merupakan salah satu faktor yang turut mempengaruhi pertumbuhan dan perkembangan anak terutama untuk kecerdasannya. Adapun indikator lingkungan sekolah adalah hubungan guru dengan siswa, hubungan siswa dengan siswa, ruang dan tempat belajar siswa, fasilitas kelas, alat pembelajaran, perpustakaan sekolah sebagai penunjang pembelajaran, ventilasi kelas dan penerangan kelas.

Menurut (Mulyasa 2008), keefektifan berkaitan dengan terlaksananya semua tugas pokok, tercapainya tujuan, ketepatan waktu, dan adanya partisipasi aktif dari anggota. Efektifitas pembelajaran ditandai dengan keaktifan siswa dalam pembelajaran, khususnya dalam pengorganisasian dan penemuan informasi. Sementara menurut (Slavin 2010), menyatakan bahwa keefektifan pembelajaran ditentukan empat indikator yaitu (1) kualitas pembelajaran, (2) kesesuaian tingkat pembelajaran, (3) insentif, dan (4) waktu.

Prestasi belajar merupakan perubahan ranah psikologis sebagai akibat pengalaman dan proses belajar siswa yang tercapai dalam kurun waktu tertentu (syah 2012). Menurut (Winkel 2009), mengemukakan bahwa prestasi belajar merupakan bukti keberprestasian yang telah dicapai oleh seseorang. Maka prestasi belajar merupakan prestasi maksimum yang dicapai oleh seseorang setelah melaksanakan usaha-usaha belajar.

Berdasarkan tinjauan pustaka di atas maka dapat dirumuskan hipotesis yang digunakan dalam penelitian adalah “Terdapat pengaruh Lingkungan Sekolah dan Keefektifan Belajar Terhadap Prestasi belajar IPS siswa SD Kip Maccini”.

\section{METODE}

Metode Penelitian ini menggunakan pendekatan kuantitatif dengan jenis penelitian ex post facto. Definisi operasional variabel meliputi prestasi belajar adalah prestasi belajar yang dicapai melalui proses kegiatan belajar mengajar. Prestasi belajar siswa dapat ditunjukkan dalam bentuk nilai yang diberikan guru berupa raport, prestasi raport, ulangan harian, ulangan semester, tugas atau yang merupakan prestasi dari beberapa bidang studi yang telah dipelajari oleh peserta didik. Lingkungan sekolah merupakan lingkungan pendidikan utama yang kedua. Siswa-siswa, guru, administrator, konselor hidup bersama dan melaksanakan pendidikan secara teratur dan terencana dengan baik. Keefektifan pembelajaran ditentukan empat indikator yaitu (1) kualitas pembelajaran, (2) kesesuaian tingkat pembelajaran, (3) insentif, dan (4) waktu. Populasi meliputi seluruh siswa SD KIP Maccini Kecamatan Makassar tahun ajaran 2018/2019 yang terdiri dari 12 rombel dengan sampel yaitu 6 kelas (rombel) SDN KIP Maccini makassar yang terdiri dari 113 siswa. 6 kelas (rombel) tersebut adalah siswa kelas III 
A, siswa kelas III B, siswa kelas IV A, siswa kelas IV B, siswa kelas V A, dan siswa kelas V B. Teknik penarikan sampel yang digunakan dalam penelitian ini adalah multistage random sampling. Teknik pengumpulan data yang digunakan dalam penelitian ini yaitu angket. Instrumen pengukuran yang digunakan dalam penelitian ini telah divalidasi empiris. Teknik Analisis Data meliputi analisis statistik desktiptif dan analisis inferensial. Analisis ini diawali dengan uji syarat analisis yaitu uji normalitas, uji linieritas, dan wilayah uji hipotesis (uji regresi).

\section{HASIL DAN PEMBAHASAN}

Hasil

Tabel 4.1. Statistik Skor lingkungan sekolah

\begin{tabular}{lc}
\hline Uraian & Besaran Statistik \\
\hline Jumlah skor & 8662 \\
Rata-rata (Mean) & 76,65 \\
Nilai Tengah (Median) & 75 \\
Standar Deviasi & 11,351 \\
Range & 42 \\
Skor minimum & 58 \\
Skor maksimum & 100 \\
\hline
\end{tabular}

Sumber: Prestasi Analisis Angket, 2019

Prestasi perhitungan statistik deskriptif yang didasarkan frekuensi pilihan responden terhadap kategori jawaban, diperoleh skor ratarata (mean) sebesar 76,65 dengan jumlah skor dari 113 responden penelitian di SD KIP

\section{Pengaruh lingkungan sekolah terhadap prestasi belajar IPS siswa kelas IV SD KIP Maccini}

a. Deskripsi lingkungan sekolah

Data prestasi analisis deskriptif variabel lingkungan sekolah pada siswa SD KIP Maccini Makassar yang diperoleh dari angket penelitian, secara umum berdasarkan prestasi angket (tabel 4.1), maka dapat dijelaskan bahwa skor tersebar pada rentang 58 (skor terendah) sampai 100 (skor tertinggi). Ringkasan prestasi analisis deskriptif variabel lingkungan sekolah pada siswa SD KIP Maccini Makassar, disajikan pada tabel 4.1 berikut:

Tabel 4.2. Distribusi Frekuensi dan Persentase Skor lingkungan sekolah

\begin{tabular}{|c|c|c|c|}
\hline Interval & lingkungan sekolah & $\mathrm{F}$ & $\%$ \\
\hline $84-100$ & Sangat nyaman & 31 & 27.43 \\
\hline $68-83$ & Nyaman & 53 & 46.90 \\
\hline $52-67$ & Cukup Nyaman & 29 & 25.66 \\
\hline $36-51$ & Kurang nyaman & 0 & 0.00 \\
\hline \multirow[t]{2}{*}{$20-35$} & Sangat kurang nyaman & 0 & 0.00 \\
\hline & Jumlah & 113 & 100,00 \\
\hline
\end{tabular}

Sumber: Prestasi Analisis Angket, 2019

Berdasarkan tabel 4.2 tentang lingkungan
sekolah pada siswa SD SD KIP Maccini
Makassar tersebut, dapat dilihat bahwa
sebagian besar responden menyatakan
lingkungan sekolah pada siswa di SD SD KIP
Maccini Makassar berada dalam kategori
sangat nyaman sebanyak 31 responden $(27,43$

Berdasarkan tabel 4.2 tentang lingkungan
sekolah pada siswa SD SD KIP Maccini
Makassar tersebut, dapat dilihat bahwa
sebagian besar responden menyatakan
lingkungan sekolah pada siswa di SD SD KIP
Maccini Makassar berada dalam kategori
sangat nyaman sebanyak 31 responden $(27,43$

Berdasarkan tabel 4.2 tentang lingkungan
sekolah pada siswa SD SD KIP Maccini
Makassar tersebut, dapat dilihat bahwa
sebagian besar responden menyatakan
lingkungan sekolah pada siswa di SD SD KIP
Maccini Makassar berada dalam kategori
sangat nyaman sebanyak 31 responden $(27,43$

Berdasarkan tabel 4.2 tentang lingkungan
sekolah pada siswa SD SD KIP Maccini
Makassar tersebut, dapat dilihat bahwa
sebagian besar responden menyatakan
lingkungan sekolah pada siswa di SD SD KIP
Maccini Makassar berada dalam kategori
sangat nyaman sebanyak 31 responden $(27,43$

Berdasarkan tabel 4.2 tentang lingkungan
sekolah pada siswa SD SD KIP Maccini
Makassar tersebut, dapat dilihat bahwa
sebagian besar responden menyatakan
lingkungan sekolah pada siswa di SD SD KIP
Maccini Makassar berada dalam kategori
sangat nyaman sebanyak 31 responden $(27,43$

Berdasarkan tabel 4.2 tentang lingkungan
sekolah pada siswa SD SD KIP Maccini
Makassar tersebut, dapat dilihat bahwa
sebagian besar responden menyatakan
lingkungan sekolah pada siswa di SD SD KIP
Maccini Makassar berada dalam kategori
sangat nyaman sebanyak 31 responden $(27,43$

Berdasarkan tabel 4.2 tentang lingkungan
sekolah pada siswa SD SD KIP Maccini
Makassar tersebut, dapat dilihat bahwa
sebagian besar responden menyatakan
lingkungan sekolah pada siswa di SD SD KIP
Maccini Makassar berada dalam kategori
sangat nyaman sebanyak 31 responden $(27,43$
Maccini Makassar. Gambaran distribusi frekuensi dan persentase lingkungan sekolah pada siswa SD SD KIP Maccini Makassar, disajikan pada tabel 4.2 berikut:

persen), kategori nyaman sebanyak 53 responden (46,90 persen), kategori cukup nyaman sebanyak 29 responden $(25,66$ persen). Sesuai nilai rata-rata skor prestasi penelitian tentang lingkungan sekolah pada siswa SD KIP Maccini Makassar sebesar 76,65. Berdasarkan tabel prestasi belajar IPS 
siswa di atas, dapat diketahui bahwa pada umumnya lingkungan sekolah IPS pada siswa SD KIP Maccini Makassar berada pada kategori tinggi (Nyaman) dengan persentase 46,90\% dengan frekuensi 53 orang responden dari 113 orang responden.

b. Prestasi uji Hipotesis I

Dalam pengujian statistiknya, hipotesis dirumuskan sebagai berikut:

$\mathrm{H}_{0}: \boldsymbol{\beta}_{1}=\mathbf{0} \mathrm{Vs} \mathbf{H}_{1}: \boldsymbol{\beta}_{1} \neq \mathbf{0}$

$\mathrm{H}_{0}$ : Tidak terdapat pengaruh yang signifikan antara lingkungan sekolah terhadap prestasi belajar IPS siswa SD KIP Maccini Makassar.

$\mathrm{H}_{1}$ : Terdapat pengaruh yang signifikan antara lingkungan sekolah dengan prestasi belajar IPS siswa SD KIP Maccini Makassar.

Dari prestasi analisis dengan SPSS diperoleh nilai signifikansi $=0.262$, terlihat bahwa 0.160 $>\alpha$ signifikansi dengan demikian $\mathrm{H}_{0}$ diterima sehingga $\mathrm{H}_{1}$ yang menyatakan bahwa terdapat pengaruh yang signifikan antara tingkat lingkungan sekolah terhadap prestasi belajar IPS siswa SD KIP Maccini Makassar ditolak.

Persamaan regresi linier $\mathrm{Y}$ (prestasi belajar IPS) atas $\mathrm{X}_{1}$ (lingkungan sekolah) yang diperoleh dari perhitungan yang telah dilakukan adalah $Y=66,72-0.151 X_{1}$.
Persamaan regresi $\mathrm{Y}$ atas $\mathrm{X}_{1}$ tersebut menunjukkan bahwa setiap kenaikan satu unit $\mathrm{X}_{1}$ akan mengakibatkan 0.151 unit penurunan $\mathrm{Y}$. Hal ini menunjukkan bahwa tidak terdapat hubungan antara $\mathrm{X}_{1}$ dengan $\mathrm{Y}$.

Besarnya koefisien determinasi $\left(\mathrm{R}^{2}\right)$ adalah 0.002 , ini berarti pengaruh atau kontribusi $\mathrm{X}_{1}$ terhadap Y adalah sebesar $0.2 \%$. Dengan kata lain variasi dalam variabel $\mathrm{Y}$ sekitar $0.2 \%$ dapat dijelaskan oleh variabel $\mathrm{X}_{1}$ melalui persamaan regresi $Y=66,72-0.151 X_{1}$, Dengan demikian hipotesis pertama yang menyatakan terdapat pengaruh yang signifikan antara lingkungan sekolah dengan prestasi belajar IPS siswa SD KIP Maccini Makassar ditolak.

\section{Pengaruh keefektifan belajar terhadap prestasi belajar IPS siswa kelas IV SD KIP Maccini}

a. Deskripsi keefektifan belajar

Data prestasi analisis deskriptif variabel keefektifan belajar siswa SD KIP Maccini Makassar yang diperoleh dari angket penelitian, secara umum berdasarkan prestasi angket (tabel 4.3), maka dapat dijelaskan bahwa skor tersebar pada rentang 57 (skor terendah) sampai 98 (skor tertinggi). Ringkasan prestasi analisis deskriptif variabel keefektifan belajar siswa SD KIP Maccini Makassar, disajikan pada tabel 4.3 berikut:

Tabel 4.3. Statistik Skor keefektifan belajar

\begin{tabular}{lc}
\hline Uraian & Besaran Statistik \\
\hline Jumlah skor & 8562 \\
Rata-rata (Mean) & 75.77 \\
Nilai Tengah (Median) & 76 \\
Standar Deviasi & 11.119 \\
Range & 41 \\
Skor minimum & 57 \\
Skor maksimum & 98 \\
\hline
\end{tabular}

Sumber: Prestasi Analisis Angket, 2019

Prestasi perhitungan statistik deskriptif yang didasarkan frekuensi pilihan responden terhadap kategori jawaban, diperoleh skor ratarata (mean) sebesar 75,77 dengan jumlah skor 8562 dari 113 responden penelitian di SD KIP Maccini Makassar. Gambaran distribusi frekuensi dan persentase keefektifan belajar siswa SD KIP Maccini Makassar, disajikan pada tabel 4.4 berikut: 
Tabel 4.4. Distribusi Frekuensi dan Persentase Skor keefektifan belajar

\begin{tabular}{cccc}
\hline Interval & Keefektifan belajar & $F$ & $\%$ \\
\hline $84-100$ & Sangat efektif & 23 & 20.35 \\
$68-83$ & Efektif & 58 & 51.33 \\
$52-67$ & Cukup efektif & 32 & 28.32 \\
$36-51$ & Kurang efektif & 0 & 0 \\
$20-35$ & Sangat kurang efektif & 0 & 0 \\
\hline & $J u m l a h$ & 113 & 100,00
\end{tabular}

Sumber: Prestasi Analisis Angket, 2019

Berdasarkan tabel 4.4 tentang keefektifan pembelajaran siswa SD KIP Maccini Makassar tersebut, dapat dilihat bahwa sebagian besar responden menyatakan keefektifan belajar siswa SD KIP Maccini Makassar dalam kategori sangat efektif sebanyak 23 responden (20,35 persen), kategori efektif sebanyak 58 responden $(51,33$ persen), kategori cukup efektif sebanyak 32 responden (28,32 persen). Sesuai nilai rata-rata skor prestasi penelitian tentang keefektifan pembelajaran siswa SD KIP Maccini Makassar sebesar 75,77 Berdasarkan tabel keefektifan pembelajaran siswa di atas, dapat diketahui bahwa pada umumnya keefektifan pembelajaran siswa SD KIP Maccini Makassar berada pada kategori kreatif (tinggi) dengan persentase $51,33 \%$ dengan frekuensi 58 orang responden dari 113 orang responden.

b. Prestasi uji Hipotesis II

Dalam pengujian statistiknya, hipotesis dirumuskan sebagai berikut:

$$
\mathbf{H}_{\mathbf{0}}: \boldsymbol{\beta}_{\mathbf{1}}=\mathbf{0} \text { Vs } \mathbf{H}_{\mathbf{1}}: \boldsymbol{\beta}_{\mathbf{1}} \neq \mathbf{0}
$$

$\mathrm{H}_{0}$ : Tidak terdapat pengaruh yang signifikan antara keefektifan belajar terhadap prestasi belajar IPS siswa SD KIP Maccini Makassar.

$\mathrm{H}_{1}$ : Terdapat pengaruh yang signifikan antara keefektifan belajar terhadap prestasi belajar IPS siswa SD KIP Maccini Makassar.

Dari prestasi analisis dengan SPSS diperoleh nilai signifikansi $=0.000$. Terlihat bahwa $\alpha>$ signifikansi dengan demikian $\mathrm{H}_{0}$ ditolak sehingga $\mathrm{H}_{1}$ yang menyatakan bahwa terdapat pengaruh yang signifikan keefektifan belajar terhadap prestasi belajar IPS siswa SD KIP Maccini Makassar dapat diterima.
Persamaan regresi linier Y (prestasi belajar IPS) atas $\mathrm{X}_{2}$ (keefektifan belajar) yang diperoleh dari perhitungan yang telah dilakukan adalah $Y=13,650+0.548 X_{2}$. Persamaan regresi $\mathrm{Y}$ atas $\mathrm{X}_{2}$ tersebut menunjukkan bahwa setiap kenaikan satu unit $\mathrm{X}_{2}$ akan mengakibatkan 0.548 unit kenaikan Y. Hal ini menunjukkan bahwa terdapat hubungan antara $\mathrm{X}_{2}$ dengan $\mathrm{Y}$

Besarnya koefisien determinasi $\left(\mathrm{R}^{2}\right)$ adalah 0.136 , ini berarti pengaruh atau kontribusi $\mathrm{X}_{2}$ terhadap $\mathrm{Y}$ adalah sebesar 13,6\%. Dengan kata lain variasi dalam variabel $\mathrm{Y}$ sekitar $13,6 \%$ dapat dijelaskan oleh variabel $\mathrm{X}_{2}$ melalui persamaan regresi $Y=13,650+$ $0.548 X_{2}$, Dengan demikian hipotesis kedua yang menyatakan terdapat keefektifan belajar terhadap prestasi belajar IPS siswa SD KIP Maccini Makassar dapat diterima.

3. Pengaruh antara lingkungan sekolah dan keefektifan belajar terhadap prestasi belajar IPS siswa kelas IV SD Kip Maccini

a. Deskripsi prestasi belajar

Data prestasi analisis deskriptif variabel prestasi belajar IPS pada siswa SD KIP Maccini Makassar yang diperoleh dari tes prestasi belajar, secara umum berdasarkan prestasi angket (tabel 4.5), maka dapat dijelaskan bahwa skor tersebar pada rentang 20 (skor terendah) sampai 100 (skor tertinggi). Gambaran distribusi frekuensi dan persentase prestasi belajar IPS pada siswa SD KIP Maccini Makassar, disajikan pada tabel 4.5 berikut: 
Tabel 4.5. Distribusi Frekuensi dan Persentase Skor Prestasi Belajar IPS

\begin{tabular}{cccc}
\hline Interval & Prestasi belajar IPS & $\mathrm{F}$ & $\%$ \\
\hline $84-100$ & Sangat tinggi & 4 & 3.54 \\
$67-83$ & Tinggi & 11 & 9.73 \\
$50-66$ & Cukup & 33 & 29.20 \\
$33-49$ & Kurang & 43 & 38.05 \\
$0-32$ & Sangat kurang & 22 & 19.47 \\
\hline & Ju m la h & 113 & 100
\end{tabular}

Sumber: Prestasi Analisis Angket, 2019

Berdasarkan tabel 4.5 tentang prestasi belajar IPS pada siswa SD KIP Maccini Makassar tersebut, dapat dilihat bahwa sebagian besar responden menyatakan prestasi belajar IPS pada siswa SD KIP Maccini Makassar berada dalam kategori sangat tinggi sebanyak 4 responden (3,54 persen), kategori tinggi sebanyak 11 responden $(9,73$ persen), kategori cukup sebanyak 33 responden $(29,20$ persen), kategori kurang sebanyak 43 responden $(38,05$ persen) dan kategori sangat kurang sebanyak 22 responden (19,47 persen). Sesuai nilai ratarata skor prestasi penelitian tentang prestasi belajar IPS pada siswa di SD KIP Maccini Makassar sebesar 55,18 Berdasarkan tabel prestasi belajar IPS siswa di atas, dapat diketahui bahwa pada umumnya prestasi belajar IPS pada siswa SD KIP Maccini Makassar berada pada kategori cukup dengan persentase 29,20\% dengan frekuensi 33 orang responden dari 113 orang responden. Ringkasan prestasi analisis deskriptif variabel prestasi belajar IPS pada siswa SD KIP Maccini Makassar, disajikan pada tabel 4.6 berikut:

Tabel 4.6. Statistik Skor Prestasi Belajar IPS

\begin{tabular}{lc}
\hline Uraian & Besaran Statistik \\
\hline Jumlah skor & 6235 \\
Rata-rata (Mean) & 55.18 \\
Nilai Tengah (Median) & 55 \\
Standar Deviasi & 16.076 \\
Range & 80 \\
Skor minimum & 20 \\
Skor maksimum & 80 \\
\hline
\end{tabular}

Sumber: Prestasi Analisis Tes Prestasi Belajar IPS, 2019

Prestasi perhitungan statistik deskriptif yang didasarkan frekuensi pilihan responden terhadap kategori jawaban, diperoleh skor ratarata (mean) sebesar 55,18 dengan jumlah skor 6235 dari 113 responden penelitian SD KIP Maccini Makassar.

b. Prestasi uji Hipotesis III

Dalam pengujian statistiknya, hipotesis dirumuskan sebagai berikut:

$$
\mathbf{H}_{\mathbf{0}}: \boldsymbol{\beta}_{\boldsymbol{i}}=\mathbf{0} \text { Vs } \mathbf{H}_{\mathbf{1}}: \boldsymbol{\beta}_{\boldsymbol{i}} \neq \mathbf{0},(\exists i \neq 0)
$$

$\mathrm{H}_{0} \quad$ : Tidak terdapat pengaruh yang signifikan secara bersama-sama antara lingkungan sekolah dan keefektifan belajar terhadap prestasi belajar IPS siswa SD KIP Maccini Makassar.
$\mathrm{H}_{1} \quad$ : Terdapat pengaruh yang signifikan secara bersama-sama antara lingkungan sekolah dan keefektifan belajar terhadap prestasi belajar IPS siswa SD KIP Maccini Makassar.

Dari prestasi analisis dengan SPSS diperoleh nilai signifikansi $=0.000$. Terlihat bahwa $\alpha>$ signifikansi dengan demikian $\mathrm{H}_{0}$ ditolak sehingga $\mathrm{H}_{1}$ yang menyatakan bahwa terdapat pengaruh yang signifikan secara bersama-sama antara lingkungan sekolah dan keefektifan pembelajaran terhadap prestasi belajar IPS siswa SD KIP Maccini Makassar dapat diterima.

Persamaan regresi linier $\mathrm{Y}$ (prestasi belajar IPS) atas $\mathrm{X}_{1}$ dan $\mathrm{X}_{2}$, (lingkungan sekolah dan 
keefektifan belajar) yang diperoleh dari perhitungan yang telah dilakukan adalah $Y=$ $14.582-0.010 X_{1}+0.545 X_{2}$. Persamaan regresi $\mathrm{Y}$ atas $\mathrm{X}_{1}$ dan $\mathrm{X}_{2}$ tersebut menunjukkan bahwa setiap kenaikan satu unit $X_{1}$ akan mengakibatkan 0.010 unit penurunan $\mathrm{Y}$, kenaikan satu unit $\mathrm{X}_{2}$ akan mengakibatkan 0.545 unit kenaikan $\mathrm{Y}$. Hal ini menunjukkan bahwa terdapat hubungan antara $X_{1}$ dan $X_{2}$ dengan $\mathrm{Y}$.

Besarnya koefisien determinasi $\left(\mathrm{R}^{2}\right)$ adalah 0.128 , ini berarti pengaruh atau kontribusi $\mathrm{X}_{1}$ dan $\mathrm{X}_{2}$ terhadap $\mathrm{Y}$ adalah sebesar $12.8 \%$. Dengan kata lain variasi dalam variabel $\mathrm{Y}$ sekitar $12.8 \%$ dapat dijelaskan oleh variabel $\mathrm{X}_{1}$ dan $\mathrm{X}_{2}$ melalui persamaan regresi $Y=$ $14.582-0.010 X_{1}+0.545 X_{2}$. Dengan demikian hipotesis pertama yang menyatakan terdapat pengaruh yang signifikan secara bersama-sama antara lingkungan sekolah dan keefektifan pembelajaran terhadap prestasi belajar IPS siswa SD KIP Maccini Makassar dapat diterima.

\section{Pembahasan}

Lingkungan sekolah membawa dampak terhadap interaksi guru dan siswa dimana siswa dapat belajar dan berpartisipasi aktif dalam mengembangkan kemampuan diri. Hubungan antara siswa dalam lingkungan sekolah terbina dalam kelompok maupun perorangan namun mampu berinteraksi dalam belajar mengajar. Ketersediaan sarana bagi lingkungan sekolah juga dapat memacu anak belajar dengan optimal dan harus didukung oleh guru. Adapun indikator lingkungan sekolah dalam penelitian ini meliputi: hubungan guru dengan siswa, hubungan siswa dengan siswa, fasilitas kelas, alat pembelajaran, perpustakaan sekolah sebagai penunjang pembelajaran, serta ventilasi kelas dan penerangan kelas.

Secara keseluruhan lingkungan sekolah ditempat penelitian menunjukkan kategori nyaman, hubungan guru dengan siswa terjalin dengan baik, sebagian besar siswa merasa nyaman dengan kemauan guru yang kuat untuk memotivasi siswa giat belajar. Hubungan siswa dengan siswa pun terlihat akrab dari hasil jawaban angket yg telah diberikan dengan menyatakan mempunyai kemauan yang kuat untuk bisa berkomunikasi yang baik dan mudah dipahami dengan siswa lain. Fasilitas dan alat pembelajaran lengkap, ventilasi dan penerangan cukup member kenyamanan pada siswa dalam belajar. Secara keseluruhan lingkungan sekolah di lokasi penelitian SD KIP Maccini Makassar berada pada kategori nyaman. Temuan tersebut sejalan dengan teori yang dikemukakan oleh (Dalyono 2015), yang menyatakan lingkungan sekolah merupakan salah satu faktor yang turut mempengaruhi pertumbuhan dan perkembangan anak terutama untuk kecerdasannya. Lingkungan sekolah sangat berperan dalam meningkatkan pola pikir anak, karena kelengkapan sarana dan prasarana dalam belajar serta kondisi lingkungan yang baik sangat penting guna mendukung terciptanya lingkungan belajar yang menyenangkan.

Senada dengan teori yang dikemukakan oleh Tu'u (2004: 18) faktor lingkungan sekolah sebagai berikut: a) Guru, Guru adalah tenaga pendidik yang memberikan sejumlah ilmu pengetahuan kepada anak didik; b) Sarana dan prasarana, Keadaan gedung sekolah dan ruang kelas yang tertata rapi, ruang perpustakaan sekolah yang teratur, tersedianya fasilitas kelas dan laboratorium, tersedianya buku-buku pelajaran, media/alat bantu belajar merupakan komponen yang penting untuk mendukung kegiatan-kegiatan belajar; c) Kondisi gedung, Apabila suasana ruang gelap, ruangan sempit, tidak ada ventilasi dan gedung rusak akan menjadikan proses belajar yang kurang baik sehingga memungkunkan proses belajar menjadi terhambat.

Dalam menjaga berjalannya sistem pembelajaran efektif biasanya guru mempersiapkan rencana pembelajaran secara matang untuk menjaga ketertarikan anak-anak untuk mengikuti pembelajaran. Faktor-faktor yang mempengaruhi keefektifan proses belajar mengajar secara global dapat dibedakan menjadi tiga macam, yaitu faktor yang berasal dari dalam diri siswa, seperti keadaan/kondisi jasmani dan rohani siswa. Faktor dari luar siswa, yakni kondisi lingkungan di sekitar siswa. Faktor pendekatan belajar, yakni jenis upaya belajar siswa yang meliputi strategi dan metode yang digunakan siswa untuk melakukan kegiatan pembelajaran materimateri pelajaran. Adapun indikator keefektifan 
belajar dalam penelitian ini adalah kualitas pembelajaran, kesesuaian tingkat pembelajaran, insentif dan waktu.

Keefektifan belajar dalam penelitian ini berada pada kategori efektif berdasarkan jawaban responden pada pernyataan yang termuat dalam angket. Dari segi kualitas pembelajaran, pada sekolah SD KIP Maccini guru sering meng-update materi pelajaran sehingga kualitas pembelajaran tergolong megikuti zaman. Dari segi kesesuaian tingkat pembelajaran, guru menyampaikan materi berdasarakan kebutuhan dan kemapuan siswa dalam menangkap dan memahami materi. Dari segi insentif, guru selalu memberikan reward/pujian kepada siswa yang mengikuti pelajaran dengan baik, tak jarang pula guru memotivasi siswa agar memperhatikan dan berpartisipasi dalam proses pembelajaran. dari segi waktu, guru menyediakan waktu yang cukup pada siswa dalam melakukan diskusi dan memberikan kesempatan pada siswa menanyakan materi yang belum dimengerti. Temuan tersebut sesuai dengan teori yang dikemukakan oleh (Mulyasa 2008), yang menyatakan keefektifan berkaitan dengan terlaksananya semua tugas pokok, tercapainya tujuan, ketepatan waktu, dan adanya partisipasi aktif dari anggota. Efektifitas pembelajaran ditandai dengan keaktifan siswa dalam pembelajaran, khususnya dalam pengorganisasian dan penemuan informasi. Oleh karena itu semakin aktif siswa dalam proses pembelajaran, semakin efektif pula pembelajaran yang dilaksanakan (Eggen dan Don Kauchak 2016).

Dari hasil analisis ditemukan bahwa terdapat pengaruh yang signifikan secara bersama-sama antara lingkungan sekolah dan keefektifan pembelajaran terhadap hasil belajar IPS siswa SD KIP Maccini Makassar. Walaupun pada variabel lingkungan sekolah tidak berarti ada pengaruh terhadap hasil belajar namun tetap memilki hubungan. Sedangkan pada variabel keefektifan belajar berpengaruh terhadap hasil belajar dan saling berhubungan satu sama lain. Secara keseluruhan terdapat pengaruh yang signifikan secara bersama-sama antara lingkungan sekolah dan keefektifan pembelajaran terhadap hasil belajar IPS siswa SD KIP Maccini Makassar.

\section{SIMPULAN DAN SARAN}

Berdasarkan hasil penelitian yang telah dilakukan tentang pengaruh lingkungan sekolah dan Keefektifan belajar terhadap Hasil Belajar IPS pada SD KIP Maccini Kecamatan Makassar Kota Makassar, disimpulkan sebagai berikut:

Lingkungan sekolah tidak memberikan pengaruh yang berarti terhadap hasil belajar IPS siswa di SD KIP Maccini.

Keefektifan belajar berpengaruh signifikan terhadap hasil belajar IPS siswa di SD KIP Maccini. Hal ini menunjukkan bahwa jika keefektifan pembelajaran tinggi maka hasil belajar siswa juga tinggi.

Lingkungan sekolah dan keefektifan pembelajaran bersama-sama berpengaruh signifikan terhadap hasil belajar IPS siswa di SD KIP Maccini. Hal ini menunjukkan bahwa interaksi antara lingkungan sekolah dan keefektifan pembelajaran akan menunjukkan hasil belajar siswa yang tinggi.

Sehubungan dengan simpulan penelitian di atas, maka disarankan sebagai berikut: (1) Untuk mencapai hasil belajar IPS yang baik bagi siswa di SD KIP Maccini hendaknya guru menciptakan lingkungan sekolah yang nyaman, serta sering mengadakan evaluasi dengan menyebar angket kepuasan terhadap lingkungan sekolah baik dari sisi siswa, guru serta warga sekolah laiinya; (2) kefektifan belajar sebaiknya di lihat pula dari sisi siswa sehingga hasil belajar yang baik dapat diperoleh secara maksimal; (3) Untuk mencapai hasil belajar IPS yang baik hendaknya lingkungan sekolah dan keefektifan pembelajaran siswa ditingkatkan karena kedua variabel tersebut berinteraksi secara bersamasama berpengaruh dalam meningkatkan hasil belajar IPS siswa di SD KIP Maccini.

\section{DAFTAR RUJUKAN}

Dalyono, M. 2015. Psikologi Pendidikan. Jakarta: Rineka Cipta. 
Eggen, Paul, dan Don Kauchak. 2016. Strategi dan Model PembelajaranMengajarkan Konten dan Keterampilan Berpikir. Jakarta: Indeks.

Hasbullah. 2013. Dasar-Dasar Ilmu Pendidikan. Jakarta: RajaGrafindo Persada.

Mulyasa, H.E. 2008. Menjadi Guru Profesional: Menciptakan Pembelajaran Kreatif dan Menyenangkan. Bandung: PT Remaja Rosda Karya.
Slavin, Robert E. 2007. Educational Psychology: Theory and Practice: Chapter 15: Current Issues and Emerging Trends. Bagian 15. Massachusetts: Allyn \& Bacon, Incorporated.

syah, Muhibbin. 2012. Psikologi Belajar. Jakarta: RajaGrafindo Persada.

Tu'u, Tulus. 2004. Peran Disiplin Pada Perilaku dan Prestasi siswa. Jakarta: Grasindo.

Winkel, W.S. 2009. Psikologi Pengajaran. Yogyakarta: Media Abadi. 